University of Nebraska - Lincoln

DigitalCommons@University of Nebraska - Lincoln

\title{
The Mind in the Mind of the Beholder: Elucidating Relational Influences on Early Social Understanding
}

Ross Thompson

University of California, Davis, California

H. Abigail Raikes

University of Nebraska-Lincoln

Follow this and additional works at: https://digitalcommons.unl.edu/psychfacpub

Part of the Psychiatry and Psychology Commons

Thompson, Ross and Raikes, H. Abigail, "The Mind in the Mind of the Beholder: Elucidating Relational Influences on Early Social Understanding" (2004). Faculty Publications, Department of Psychology. 345. https://digitalcommons.unl.edu/psychfacpub/345

This Article is brought to you for free and open access by the Psychology, Department of at DigitalCommons@University of Nebraska - Lincoln. It has been accepted for inclusion in Faculty Publications, Department of Psychology by an authorized administrator of DigitalCommons@University of Nebraska - Lincoln. 
Published in Behavioral and Brain Science 27:I (February 2004), pp. 126-127. Copyright (C) 2004 Cambridge University Press. Used by permission.

\section{The mind in the mind of the beholder: Elucidating relational Influences on early social understanding}

\author{
Ross A. Thompson ${ }^{\mathrm{a}}$ and H. Abigall Raikes ${ }^{b}$ \\ a Department of Psychology, University of Californla, Davis, Davis, CA 95616- \\ 8686; 'Department of Psychology, University of Nebraska, Lincoln, NB \\ 68688-0308. rathompson $\odot$ ucdavis,edu aralkes1 1 bigred.unl.edu \\ http://psychology.ucdavis,edu/taculty/pgms/page,ctm?Person|D=156
}

\footnotetext{
Abstract: Relational experiences shape emergent soclal understanding, and two influences deserve particular attention. First, parent-cliuld conversation about shared experiences lịcorporates both implicit and explicit information about mental states that catalyzes the sochlil construction of understanding, especially in juxtapesition with the ehild's direct experience: Second, emotion infuses the contexts and ognitions about soctal experiences that provoke the child's constructivist efforts.
}

There have already been many responses to what Carpendale \& Lewis (C\&L) are calling for in the target article; namely, greater theoretical attention to the influence of social interaction on the development of children's social understanding. These include Rogoff's (1990) constructivist view of the appropriation of social cognition in shared activity, Nelson's (1996) portrayal of the growth of the linguistically mediated mind, and the incuiry of theory-of-mind researchers into social influences on psichological understanding (e.g., Ligattuta \& Wellman 201)2). Soctiul developmentalists have also been concemed with the influence of social interaction on mental representation. Attachment theorists, for example, believe that representations (or "internal working models") of people, self, and relationships arise from varintions in attachment security and pattems of communication shared within secure or insecure parent-child relationships (Bretherton \& Munholtand 1999).

The view that communication within salient relationships shapes early social understanding provides an opportunity to better understand the processes by which social interaction is influential. This is one of the future directions for research identified by C\&L, but we believe there are at least two relational influences that are neglected in their analysis and that desterve greater attention. The first concens explicit and inplicit lentures of comversational discourse between parents and children. There is now an expanding research literature showing that mothers' conversational style with young offspring - especially; the extent of the elaborative detail, contextual information, anid provocative questions mothers provide - contributes not only to the sophistication of children's event representation but also to their understanding of emotions, conscience development, autuhiographical memory. and other features of social cognitive growth (Thompson 1998). Maternal conversational references to people's leelings and emotions are also related to young children's emotion and moral understanding (Thompson et al. 2003).

Mothers in secure attachment relationships are more elaborative in conversational discourse (and also make nore frequent references to emotion), and this may be one reason for the working models their offspring develop (Thompson 2000). Ehborative discourse about shared experiences in the context of a generally warm, secure relationship may enhance children's receptiveness to the understanding of psychological states embedded within such conversations. For this reason, we are exploring in current research the nssociation between inaternal "mind-mindedness" (Meins 1999) and elaborative discourse to elucidate aventues by which attachment security and social cognitive development may be related. This work ulso offers avenues for clarifying the nature and developinent of the "internal working models" of interest to attachment researchers (Thompson \& Reikes 20033).

Discourse quality in parent-child conversation is important not only for the reasons identified by C\&L (e.g., as a neums for becoming aware of beliefs; as a way of representing false belief in contrast to reality), but also as a meems for understanding the social constructivist processes within relationships that they emphasize. In conversation about shared experiences, the secondary representations provided in parental discourse are juxtaposed with the child's direct representations through experience; and the convergence, dissonance, complementarity, and differential focus of these representations are a rich busis for the constructivist processes described by $C \& L$, because parents and children often perceive shared experiences differently (Levine et al. 1999).

This work therefore significantly expands the authors' proposals for how relationships influence social-cognitive growth in early childhood, and suggests also that relational quality as well as variations in the nature of parent-child discourse - including nonverbal features of parent-child conversations, such as affect, gesture, and context - contribute significantly to representations of mental and psychological functioning of young children. Early parentchild conversations are important not only because they offer guidance to young children concerning the relations between behavior and people's thoughts, feelings, and beliefs, but because 
they also include implicit and explicit moral judgments, intentionality attributions, and even characterological ascriptions to the child that are likely to contribute significantly to the construction of social and psychological understanding.

Furthermore, the context of shared conversation is important. Contrary to C\&L, conflict as well as comity is a salient comversational context because nothing focuses a young child's attention on differing mental states than the realization that conflict with another must be managed. Thus, maternal verbal conflict-resolution strategies in shared conversation during disputes, such as mother's use of justifications, references to emotions, and limited use of threatening or intimidating tactics, predict young children's emotional and moral development months later (Laible \& Thompson $2002)$.

The second feature of social interaction highlighted by these findings - and largely neglected by C\&L - is emotion. Young children's efforts to manage and comprehend their feelings and the emotions of others are significant catalysts to understanding mental states, and such experiences constitute salient interactional contexts in which mental state differences are the focus of shared observation and communication. This is true from the inauguration of the "epistemic triangle" in infancy, as emotions contribute to self-other differentiation and contexts of shared reference and joint attention (such as in social referencing). Moreover, emotion organizes early understanding of mental states by comecting emotion to broader emergent representations of relationships, self-referent beliefs, and comprehension of behavioral expectations. Emotion is important, therefore, because it is not only thinking about emotion (which has been the focus of much theory-ofmind research) but thinking with emotion about self and others that stimulates early social understanding. This is one reason why in our studies (see Thompson et al. 2003) as well as others (Lagattuta \& Wellman 2002), relational influences are especially apparent in children's conversations about and comprehension of negative emotional events. Constraint and cooperation are both conceptually provocative experiences for young children.

In sum, emotion is often salient to the activity that contributes to social understanding. In early childhood, moreover, conversation about these experiences with an adult who elaborates the child's direct experience, in the context of a warm, secure relationship, provides a rich basis for the child's construction of social understanding. This social constructionist view provides provocative opportunities to integrate the focus on normative development, emphasized by students of early conceptual growth, with the focus on individual differences emphasized by students of early sociopersonality development. 